\title{
INDUCING PLANT RESISTANCE AGAINST SALINITY USING SOME RHIZOBACTERIA
}

\author{
Amal M. Omer \\ Department of Soil Fertility and Microbiology, Desert Research \\ Center, El-Matareya, Cairo, Egypt \\ E-mail: amal_omaram@yahoo.com
}

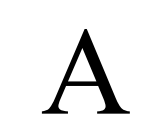

ctivity of 1-aminocyclopropane-1-carboxylate (ACC)deaminase of rhizobacteria isolated from salt-stressed rhizospheres were screened based on their utilization of ACC as sole nitrogen source. Twenty percentage of the isolates achieved remarkable differences in the activities of ACC-deaminase ranged from 180 to $1398 \mathrm{~nm} \alpha$-ketobutyrate $\mathrm{mg}^{-1} \mathrm{~h}^{-1}$. Phylogenetic analysis of 16S rRNA sequence of two strains with the highest level of ACC-deaminase activity revealed the first isolate was identified as Alcaligenes faecalis subsp. parafaecalis strain $\mathrm{G}$ and the second as Alcaligenes faecalis strain NBRC 13111. The influence of ACCdeaminase rhizobacteria on the ACC-induced classical triple response in etiolated wheat seedlings were studied. Results revealed that exogenous application of $3 \mathrm{mmol} \mathrm{L}^{-1} \mathrm{ACC}$ creating classical triple response in seedlings under salt stress $(10 \% \mathrm{NaCl})$. Inoculation with two ACC-deaminase rhizobacteria decreased the ACC-imposed classical triple response in etiolated seedlings, as significant increases in seedling length, root elongation and reduction in stem diameter over uninoculated ACC-stressed control were recorded. Studying the effect of salinity ranged from 0 to $10 \%$ $\mathrm{NaCl}$ on the growth and ACC-deaminase activitiy of the two bacterial strains revealed that gradual reduction in both growth and enzyme activity were demonstrated with increasing salinity. Both strains could tolerate the salinity up to $7 \% \mathrm{NaCl}$, A. faecalis strain $\mathrm{G}$ showed the highest ACC-deaminase activity at $1 \%$ concentration of $\mathrm{NaCl}$, while A. faecalis strain NBRC recorded the highest enzyme activity at $3 \% \mathrm{NaCl}$.

Two field experiments were conducted during 2014/15 and 2015/20116 at Ras Sudr Experimental Station to evaluate the effect of ACC-deaminase bacteria on the growth and productivity of wheat under salt stress condition. For all yield traits and chemical constituents of wheat grains, significant increase were recorded under ACC-deaminase bacterial inoculation comparing to control in both seasons of planting. The highest increase in the total microbial 
counts, $\mathrm{CO}_{2}$ evolution and dehydrogenase activity of the rhizosphere regions were indicated in plants inoculated with bacterial strains regardless the type of bacteria used. The results indicated that inoculation with ACC-deaminase rhizobacteria can serve as promising economical alternative alleviated plant stress caused by salinity.

Keyword: Alcaligenes faecalis, ACC-deaminase activity, salinity, wheat

The productivity and cultivation of agricultural crops have affected by various environmental stresses, one of the most devastating environmental stresses is soil salinity, which causes major reductions in cultivated land area, crop productivity and quality (Yamaguchi and Blumwald, 2005 and Shahbaz and Ashraf, 2013). It has been estimated that worldwide $20 \%$ of total cultivated and $33 \%$ of irrigated agricultural lands are afflicted by high salinity. Furthermore, the salinized areas are increasing at a rate of $10 \%$ annually for various reasons, including high surface evaporation, irrigation with saline water, and poor cultural practices. It has been estimated that more than $50 \%$ of the arable land would be salinized by the year 2050 (Jamil et al., 2011). Effect of salinity on limiting the productivity of crop plants depending on the sensitivity of these crop plants to concentrations of salts in the soil or irrigation water. Salt stressed soils are known to suppress the growth of plants (Paul, 2012).

While ethylene, which found in all higher plants, is an important phytohormone for normal plant growth and development in plants, it is also a key feature in the response of plants to a wide range of stresses. Overproduced ethylene under stressed conditions can result in the inhibition of plant growth or death, especially for seedlings. When plants exposed to biotic or abiotic stress conditions, ethylene is synthesized, resulting in retarded root growth and senescence (Ma et al., 2003 and Arshad et al., 2008). Ethylene is synthesized in plant tissues from its immediate precursor 1-aminocyclopropane-1-carboxylate (ACC).

Degradation of the ethylene precursor ACC into $\alpha$-ketobutyrate and ammonia by bacterial ACC-deaminase lowers the ethylene concentration in plant roots, relieves the ethylene repression of auxin response factors synthesis, and indirectly increases plant growth (Glick et al., 2007 and Kang et al., 2010). It has been proposed that ACC might be exuded from plant roots and that soil bacteria containing ACC-deaminase could convert this for their growth. As a result, the hydrolyzed ACC products would enhance bacterial growth. Taken together, the ACC-deaminase function seems to be mutually beneficial between plants and PGPR, because ethylene in plants can be reduced by continuous ACC secretion and degradation by bacteria, and bacteria can use metabolized ACC (Glick et al., 1998).

Egyptian J. Desert Res., 67, No. 1, 187-208 (2017) 
Plant growth-promoting rhizobacteria (PGPR), which is known as beneficial root-colonization bacteria have an direct or indirect useful role in enhancing plant growth, yield and nutrient uptake through various mechanisms of action (Mantelin and Touraine, 2004). Some bacterial strains directly regulate plant physiology by facilitating the nutrient uptake through phytohormone production (e.g. auxin, cytokinin and gibberellins), increasing mineral and nitrogen availability in the soil and/or by producing siderophores (Kohler et al., 2006). Indirect promotion occurs when PGPRinduced physical and chemical changes that result in preventing growth restricting conditions (Glick et al., 1999) and so enhancing tolerance to abiotic stress, which is termed Induced Systemic Resistance (ISR). One mechanism for inducing ISR of the plants is the production of ACCdeaminase enzyme by certain PGPR and this enzyme cleaves ACC, the immediate precursor of ethylene, to form $\alpha$-ketobutyrate and ammonium and thereby lowers the level of ethylene in developing or stressed plants (Jacobson et al., 1994; Glick, 1995 and Glick et al., 1998) and in this way promote plant growth.

The PGPR containing ACC-deaminase are present in various soils and offer promise as a bacterial inoculum for improvement of plant growth, particularly under unfavorable environmental conditions such as flooding, heavy metals, phyto pathogens, drought and high salt. Inoculation of crops with ACC-deaminase-containing PGPR may enhance plant growth by alleviating negative effects of salt stress ethylene (Belimov et al., 2001). A decreased ethylene level allows the plant to be more resistant to a wide variety of environmental stresses (Glick, 2005) such as salinity, drought and metal toxicity. So, plants that are inoculated with ACC-deaminase rhizobacteria are more resistant to the injurious effects of stress ethylene that is produced as a result of stressed environments such as drought and high salt concentration (Kausar and Shahzad, 2006 and Nadeem et al., 2007). This study was conducted to isolate, identify highly efficient ACC-deaminase bacteria from rhizosphere and investigate its effect on plant growth under salt stressed condition.

\section{MATERIALS AND METHODS}

\section{Isolation of Rhizobacteria}

Rhizobacteria were isolated by dilution plate technique on TSA (Tryptic Soy Agar) medium from the rhizosphere of different salt-stressed plants cultivated in saline fields at Ras-Sudr, El-Maghara and Sahl El-Tina. The collected rhizobacterial isolates were purified by further streaking on fresh plates and stored in $20 \%$ glycerol at $-20^{\circ} \mathrm{C}$. 


\section{Screening for Rhizobacterial ACC-deaminase Activity}

All bacterial isolates were screened for their ACC-deaminase activity based on their ability to use ACC as a sole nitrogen source. All isolates were grown in $5 \mathrm{ml}$ of TSB medium incubated at $28^{\circ} \mathrm{C}$ at $120 \mathrm{rpm}$ for $48 \mathrm{~h}$. The cells were harvested by centrifugation at $3000 \mathrm{rpm}$ for $5 \mathrm{~min}$, washed, resuspended in $1 \mathrm{ml}$ of $0.1 \mathrm{M}$ Tris- $\mathrm{HCl}(\mathrm{pH} 7.5)$ and inoculated on Petri plates containing modified DF (Dworkin and Foster) salts minimal medium (Dworkin and Foster, 1958), supplemented with $3 \mathrm{mM}$ ACC as sole nitrogen source. Plates containing only DF salts minimal medium without ACC served as negative control, while with $\left(\mathrm{NH}_{4}\right)_{2} \mathrm{SO}_{4}(0.2 \%$ w/v) as positive control. The plates were incubated at $28^{\circ} \mathrm{C}$ for $72 \mathrm{~h}$. Growth of isolates on ACC supplemented plates was compared to negative and positive controls to select isolates utilizing ACC as nitrogen source.

\section{ACC-deaminase Activity Assay}

Quantitative measurement of ACC-deaminase activity was carried out according to a modified methods of Honma and Shimomura (1978) and Penrose et al. (2001) by measuring the amount of $\alpha$-ketobutyrate generated by the cleavage of ACC by ACC-deaminase. For inducing ACC-deaminase activity, bacterial isolates were grown in $5 \mathrm{ml}$ of TSB medium at $28^{\circ} \mathrm{C}$ for 48 hours, the cells were collected by centrifugation, washed, suspended in $5 \mathrm{ml}$ of modified DF minimal medium supplemented with $3 \mathrm{mM}$ final concentration of ACC and incubated at $28^{\circ} \mathrm{C}$ with shaking for another $72 \mathrm{~h}$. The induced bacterial cells were harvested by centrifugation at 3,000 rpm for 5 min, washed twice with buffer ( $\mathrm{pH} 7.5$ ), and resuspended in $200 \mu 1$ of 0.1 $\mathrm{M}$ Tris- $\mathrm{HCl}(\mathrm{pH} 8.5)$. The cells were labilized by adding $300 \mu \mathrm{l}$ of $5 \%$ toluene and vortexed for 30 seconds. Fifty $\mu 1$ of labilized cell suspension was incubated with $5 \mu 1$ of $0.3 \mathrm{M} \mathrm{ACC}$ in an Eppendorf tube at $28^{\circ} \mathrm{C}$ for 30 min. All sample measurements are carried out in triplicate. Blank included $50 \mu 1$ of $0.1 \mathrm{M}$ Tris- $\mathrm{HCl}(\mathrm{pH} 8.5)$ with $5 \mu 1$ of $0.3 \mathrm{M}$ ACC. The samples were then mixed thoroughly with $500 \mu 1$ of $0.56 \mathrm{~N} \mathrm{HCl}$ by vortexing and the cell debris was removed by centrifugation at $12,000 \mathrm{~g}$ for $5 \mathrm{~min}$. A $500 \mu 1$ aliquot of the supernatant was transferred to a glass test tube and mixed with $400 \mu 1$ of $0.56 \mathrm{~N} \mathrm{HCl}$ and $150 \mu \mathrm{l}$ of DNF solution $(0.1 \mathrm{~g}$ 2,4dinitrophenylhydrazine in $100 \mathrm{ml}$ of $2 \mathrm{~N} \mathrm{HCl}$ ); and the mixture was incubated at $28^{\circ} \mathrm{C}$ for $30 \mathrm{~min}$. One $\mathrm{ml}$ of $2 \mathrm{~N} \mathrm{NaOH}$ was added to the sample before the absorbance at $540 \mathrm{~nm}$ was measured. The values for absorbance versus $\alpha$-ketobutyrate concentration ( $\mathrm{mM}$ ) were used to construct a standard curve. ACC-deaminase activity was expressed as nmol aketobutyrate $\mathrm{g}^{-1}$ biomass $\mathrm{h}^{1}$.

Egyptian J. Desert Res., 67, No. 1, 187-208 (2017) 


\section{Identification of the Two ACC-deaminase}

Two selected isolates were identified to molecular level using partial 16S rRNA gene sequence technique according to (Berg et al., 2002) in Sigma Scientific Services Co. The bacterial 16S rRNA gene sequences were amplified by PCR using the following universal 16S primers:

F:- AGA GTT TGA TCC TGG CTC AG

R:- GGT TAC CTT GTT ACG ACT T

The PCR was performed by using a total volume of $20 \mu$ containing $1 \times$ Taq \& Go (MP Biomedicals, Eschwege, Germany), $1.5 \mathrm{mM} \mathrm{MgCl}, 0.2$ $\mathrm{mM}$ of each primer and $1 \mu \mathrm{l}$ of template DNA $\left(95^{\circ} \mathrm{C}, 5 \mathrm{~min} ; 30\right.$ cycles of 95 ${ }^{\circ} \mathrm{C}, 30 \mathrm{~s} ; 57^{\circ} \mathrm{C}, 30 \mathrm{~s} ; 72^{\circ} \mathrm{C}, 90 \mathrm{~s}$; and elongation at $\left.72^{\circ} \mathrm{C}, 5 \mathrm{~min}\right)$. The PCR product was purified using Gene JET ${ }^{\mathrm{TM}}$ PCR Purification Kit (Thermo K0701). The sequencing to the PCR product was performed by using ABI 3730xl DNA sequencer by using forward and reverse primers (Lane, 1991). The sequences obtained from bacterial isolates were analyzed using BLAST tool at the National Center for Biotechnology Information database (NCBI) Gene Bank database using the Basic Local Alignment Search Tool (BLAST) analysis tools (Altschul et al., 1990) to identify the most similar 16S rRNA sequences available in the Gene Bank.

\section{Effect of Salt Concentrations on Bacterial Growth and ACC- deaminase Activities}

To determine the activity of ACC-deaminase under salinity, different concentrations of $\mathrm{NaCl}$ were used ranged from 0 to $10 \% \mathrm{NaCl}$. The growth densities were estimated using spectrophotometer at $600 \mathrm{~nm}$. And the ACC-deaminase activity was carried out at each concentration as described above.

\section{Effect of ACC and Rhizobacteria on Classical Triple Response Bioassay}

The effect of $\mathrm{C}_{2} \mathrm{H}_{4}$ released from ACC on etiolated wheat seedlings were demonstrated by using the classical triple response bioassay, which is considered as one of the most specific actions of $\mathrm{C}_{2} \mathrm{H}_{4}$ (Neljubow, 1901). For this, wheat seeds were surface sterilized by dipping in $95 \%$ ethanol solution for $5 \mathrm{~min}$, and washed thoroughly with sterilized water (Khalid et al., 2006). Treated seeds were dipped for $5 \mathrm{~min}$ in the bacterial inoculum, each containing $10^{7}-10^{8} \mathrm{cfu} \mathrm{ml}^{-1}$, five seeds were sown in $100 \mathrm{ml}$ beaker lined with sterilized filter paper, wrapped with foil and treated with the following treatments:

- Distilled water as control

- Distilled water with $10 \% \mathrm{NaCl}$ (Maximum salt concentration can be tolerated by wheat seeds)

- Distilled water with $10 \% \mathrm{NaCl}, 3 \mathrm{mmol} \mathrm{L}^{-1} \mathrm{ACC}$

Egyptian J. Desert Res., 67, No. 1, 187-208 (2017) 
- Distilled water with $10 \% \mathrm{NaCl}, 3 \mathrm{mmol} \mathrm{L}^{-1} \mathrm{ACC}$ and Alcaligenes faecalis strain $\mathrm{G}$

- Distilled water with $10 \% \mathrm{NaCl}, 3 \mathrm{mmol} \mathrm{L}^{-1} \mathrm{ACC}$ and Alcaligenes faecalis strain NBRC

All the treatments were replicated four times. The beakers were incubated in complete darkness throughout the experiment at $24 \pm 3^{\circ} \mathrm{C}$. After 15 days, classical "triple" response was observed by recording seedling, root lengths and stem diameter. Also, seedling weight were recorded.

\section{Field Experiment}

Two field experiments were conducted in winter season during 2014/15 and 2015/2016 at Ras Sudr Experimental Station, South Sinai to evaluate the effect of ACC-deaminase bacteria on the growth and productivity of wheat (Sakha 94) under saline sandy loam soil irrigated with saline water. For bacterial treatments, wheat grains were moistened in CMC solution (1\%) before application of bacterial inoculum (single strain and mixture of both strains) to get a thin, uniform coating of bacteria inoculum on seeds. Inoculated seeds were dried in shade before sowing (Samasegaran et al., 1982), untreated control seeds were maintained. The experiments were designed in a completely randomized design with three replications. Phosphatic fertilizer as calcium super phosphat $\left(15.5 \% \mathrm{P}_{2} \mathrm{O}_{5}\right)$ was added at a rate of $150 \mathrm{~kg} /$ feddan. during seed bed preparation, $100 \mathrm{~kg}$ of potassium sulphate $\left(50.0 \% \mathrm{~K}_{2} \mathrm{SO}_{4}\right)$ was added at flowering stage, whereas nitrogen fertilizer was applied as ammonium sulfate $(20.5 \% \mathrm{~N})$ at rate of 250 $\mathrm{kg} /$ feddan (half of recommended dose), where $1 / 3$ of the amount was incorporated in dry soil before sowing, $1 / 3$ was added one month after sowing and the rest was added one week pre flowering stage. The investigated soil is irrigated with saline water $\left(\mathrm{EC}\right.$ about $\left.7.94 \mathrm{dSm}^{-1}\right)$, which is considered to be the main source of irrigation water in this area. Some mechanical and chemical properties of the soil and the average characteristics of chemical analysis of well irrigation water are presented in table (1).

At harvest, the following traits were estimated: plant height, number of spikes/plant, 1000-grain weight, grain yield/plant, straw yield/plant and biological yield. Chemical analysis of wheat grains including total nitrogen, phosphorus and carbohydrate according to Bremner and Mulvaney (1982), Watanabe and Olsen (1965) and Dubois et al. (1956), respectively.

Egyptian J. Desert Res., 67, No. 1, 187-208 (2017) 
Table (1). Some mechanical and chemical properties of the studied soil and chemical analysis of irrigation water.

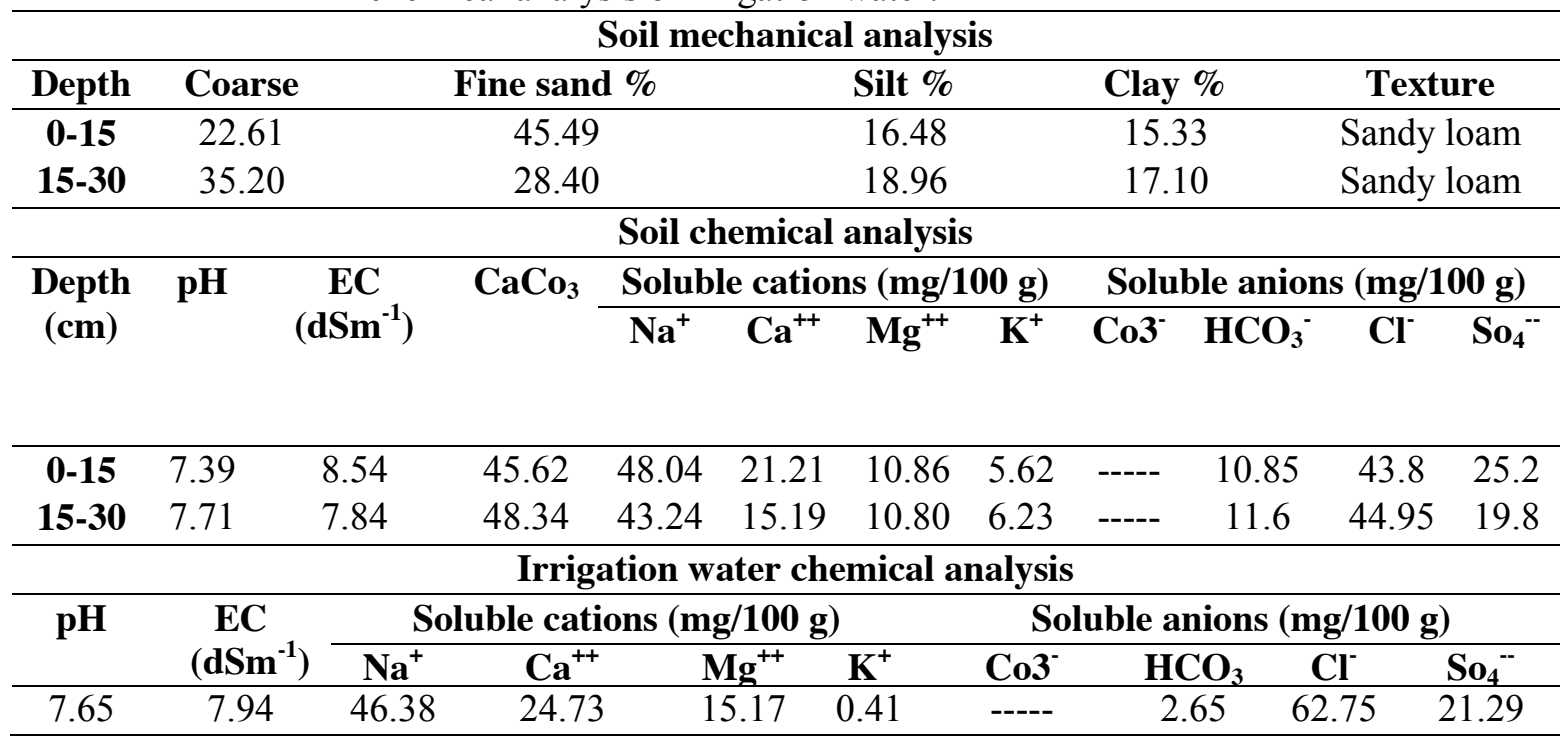

\section{Microbiological Analysis of Wheat Rhizosphere}

Total bacterial were counted on nutrient medium. $\mathrm{CO}_{2}$ evolution $(\mu \mathrm{g} / \mathrm{g}$ dry soil $/ \mathrm{h})$ in the rhizosphere were determined according to Parmer and Schmidt (1964). Soil dehydrogenase activity ( $\mu \mathrm{g}$ TPF/g dry soil/24 h) was analyzed by the reduction of 2,3,5-triphenyl tetrazolium chloride (TTC) to triphenyl formazan (TPF) as described by Pepper et al. (1995). Briefly, one $\mathrm{ml}$ of $3 \%$ TTC solution, $2.5 \mathrm{ml}$ pure water and $30 \mathrm{mg}$ glucose were added to $6 \mathrm{~g}$ of soil and the samples were incubated for $24 \mathrm{~h}$ at $37^{\circ} \mathrm{C}$. The sample was then blended with $20 \mathrm{ml}$ of methanol and shaked at $200 \mathrm{rpm}$ for $1 \mathrm{~h}$, followed by filtering to extract TPF. The optical density of the filtrate was measured at $485 \mathrm{~nm}$ in spectrophotometer.

\section{Statistical Analysis}

Data were subjected to statistical analysis using the method described by Snedecor and Cochran (1990). The least significant difference (L.S.D.) was used to differentiate means according to Waller and Duncan (1969).

\section{RESULTS AND DISCUSSION}

\section{Screening of ACC-deaminase Bacteria}

All bacterial isolates were screened for ACC-deaminase based on using ACC as sole nitrogen source. Among 45 isolates, only nine isolates represented $20 \%$ of the studied isolates grew well on DF salt minimal 
medium with either ACC or ammonium sulfate serving as the sole nitrogen source, which was compared with DF salt minimal medium without nitrogen source. Results in table (2) show only isolates could use ACC as sole nitrogen source. Govindasamy et al. (2009) used the utilization of ACC as a sole nitrogen source for growth of rhizobacteria as criterion to select the isolates possessing ACC-deaminase activity. Low frequency of ACC utilization was reported in different rhizobacterial isolates and it varied from $3.86 \%$ in peanut rhizosphere (Dey et al., 2004), 10.91\% among bacterial isolates obtained from 35 different soil samples (Peyachoknagul et al., 1997) and only $11.59 \%$ among rhizobial strains (Duan et al., 2009).

Table (2). Screening of rhizobacteria utilizing ACC as sole nitrogen source.

\begin{tabular}{cccccccccc}
\hline Media used & MC3 & SW2 & RW5 & MB1 & SW2 & MB3 & RB1 & SB3 & RB4 \\
\hline DF & + & - & + & + & + & + & + & - & + \\
DF + ACC & ++ & ++ & +++ & ++ & +++ & ++ & +++ & ++ & ++ \\
DF + Amm & +++ & ++ & +++ & ++ & +++ & +++ & +++ & ++ & ++ \\
sulfate & & & & & & & & & \\
\hline
\end{tabular}

- Site of rhizobacteria isolation: M: El-Maghara, S: Sahl El-Tina, R: Ras sudr

- Plants from which rhizobacteria isolated: C: Corn, W: wheat, B: Barley

ACC- deaminase activitiy of the isolates, which could use ACC as sole nitrogen source were measured as shown in fig. (1). Remarkable differences in the activities of ACC-deaminase were existed among the isolates, that the enzyme activities ranged from 180 to $1398 \mathrm{~nm} \alpha$ ketobutyrate $\mathrm{mg}^{-1} \mathrm{~h}^{-1}$. Two strains coded as RW5 and RB1 achieved the highest level of ACC-deaminase activity among other isolates (Fig. 1) and selected for further investigations. As indicated by Safa and Ali (2011), among rhizobacteria associated with natural plant Vigna radiata, the highest ACC-deaminse activity was exhibited by Bacillus pumilus $\left(430 \mathrm{nmol} \mathrm{h}^{-1}\right)$, Alcaligenes sp. $\left(390 \mathrm{nmol} \mathrm{h}^{-1}\right)$ and Providencia vermicola $\left(377 \mathrm{nmol} \mathrm{h}^{-1}\right)$. 


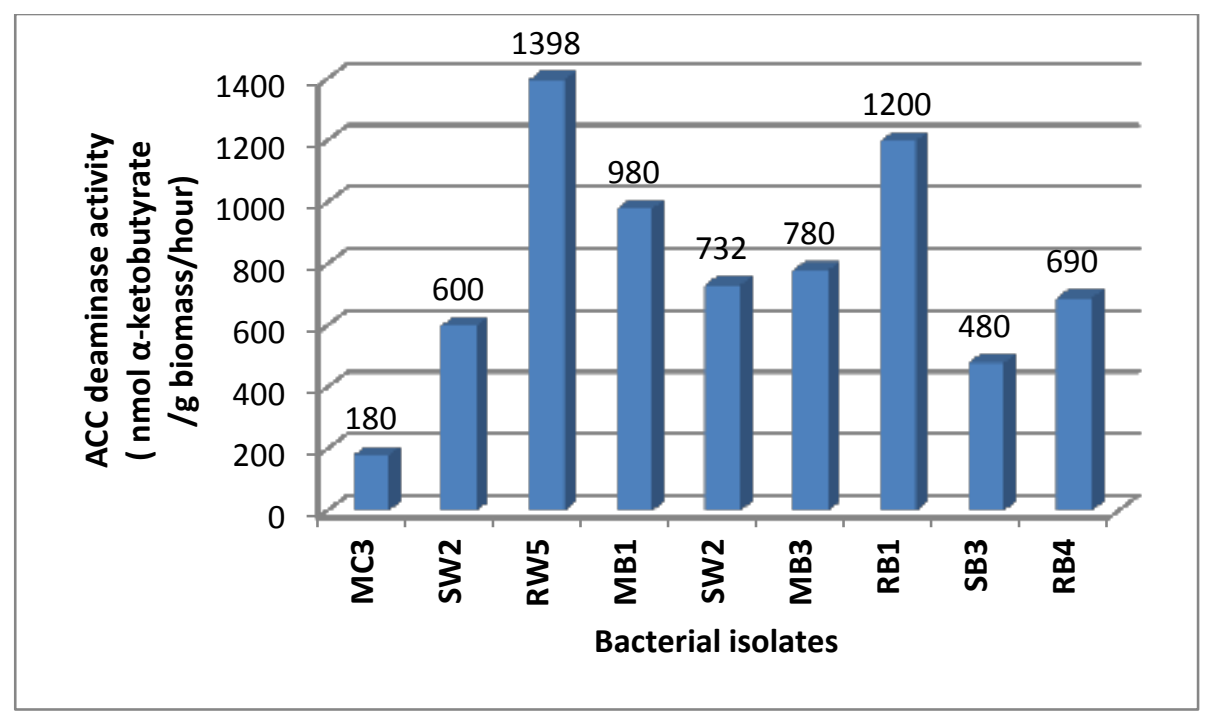

Fig. (1). ACC-deaminase activitiy of the bacterial isolates.

\section{Identification of the Most Efficient ACC-deaminase Bacteria}

Phylogenetic analysis of 16S rRNA sequence of the two ACCdeaminase bacterial isolates revealed the first isolate RW5 showed the maximum sequence similarity (99\%) with Alcaligenes faecalis subsp. parafaecalis strain $\mathrm{G}$, while the maximum sequence similarity of the second isolate RB1 was (99\%) with Alcaligenes faecalis strain NBRC 13111 (Fig. 2 and 3 ). When the nucleotide sequences were submitted, Gene Bank assigned NCBI accession number as NR 025357.1 and NR 113606.1 for Alcaligenes faecalis subsp. parafaecalis strain $\mathrm{G}$ and Alcaligenes faecalis strain NBRC 13111 , respectively.

\section{Effect of Salinity on the Growth and ACC-deaminase Activitiy of the Two Bacterial Strains}

Growth of the two bacterial strains at different levels of salinity ranged from 0 to $10 \% \mathrm{NaCl}$ was recorded in fig. (4). Results indicated that both bacterial strains could tolerate the salinity up to $7 \% \mathrm{NaCl}$ and the growth of two bacterial strains decreased as salinity of the growth medium increased. Dramatic reduction in the growth of $A$. faecalis strain $\mathrm{G}$ and $A$. faecalis strain NBRC was observed at 7 and $5 \%$ concentration of $\mathrm{NaCl}$, respectively. Ping et al. (1998) indicated that Alcaligenes faecalis A1501 isolated from paddy soils in South China in 1980, could grow well in solid or liquid medium containing $0.8 \mathrm{~mol} / \mathrm{L} \mathrm{NaCl}$ and repressed in solid medium containing $1.2 \mathrm{~mol} / \mathrm{L} \mathrm{NaCl}$. 
For enzyme activity, A. faecalis strain G showed the highest ACCdeaminase activity at $1 \%$ concentration of $\mathrm{NaCl}(2652 \mathrm{~nm} \alpha$-ketobutyrate $\mathrm{mg}^{-1} \mathrm{~h}^{-1}$ ), while A. faecalis strain NBRC recorded the highest enzyme activity at $3 \%\left(1872 \mathrm{~nm} \alpha\right.$-ketobutyrate $\left.\mathrm{mg}^{-1} \mathrm{~h}^{-1}\right)$ and then gradual reduction in the enzyme activity with increasing salinity concentration were demonstrated as in fig. (5). No enzyme activity was recorded at $9 \%$ concentration of $\mathrm{NaCl}$ for both strains. Bacillus licheniformis selected for its ability to utilize ACC as a sole nitrogen source under salinity stress showed a high ACC-deaminase activity at $0.6 \mathrm{M} \mathrm{NaCl}$ salinity (Kannika and Maneewan, 2012).

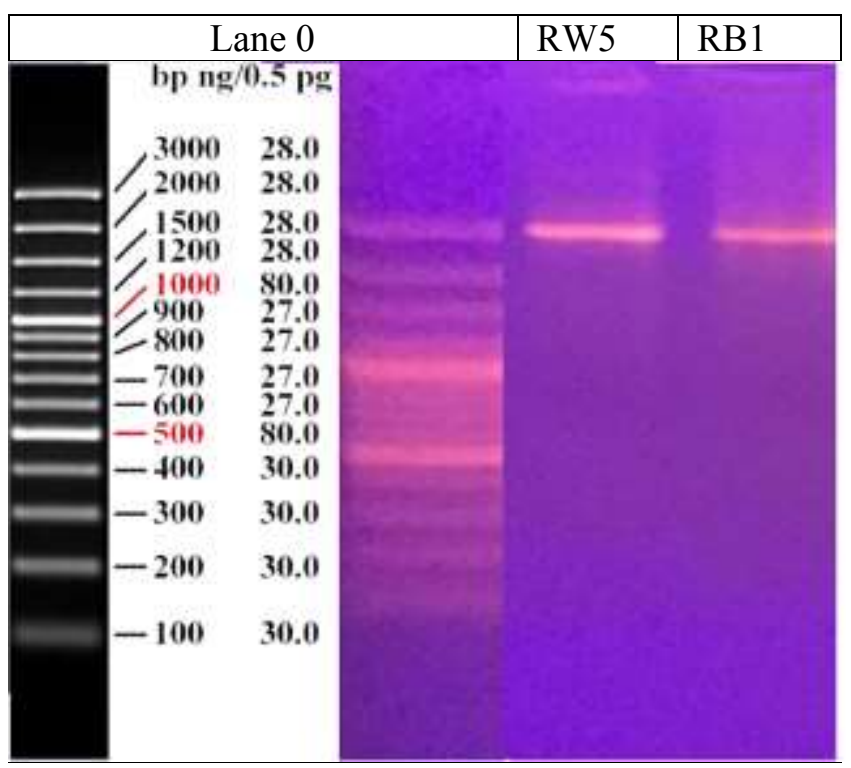

Fig. (2). PCR profiles of 16S rRNA fragments amplification of the isolates (RW5 and RB1), lane 0; 100 pb plus DNA ladder. 

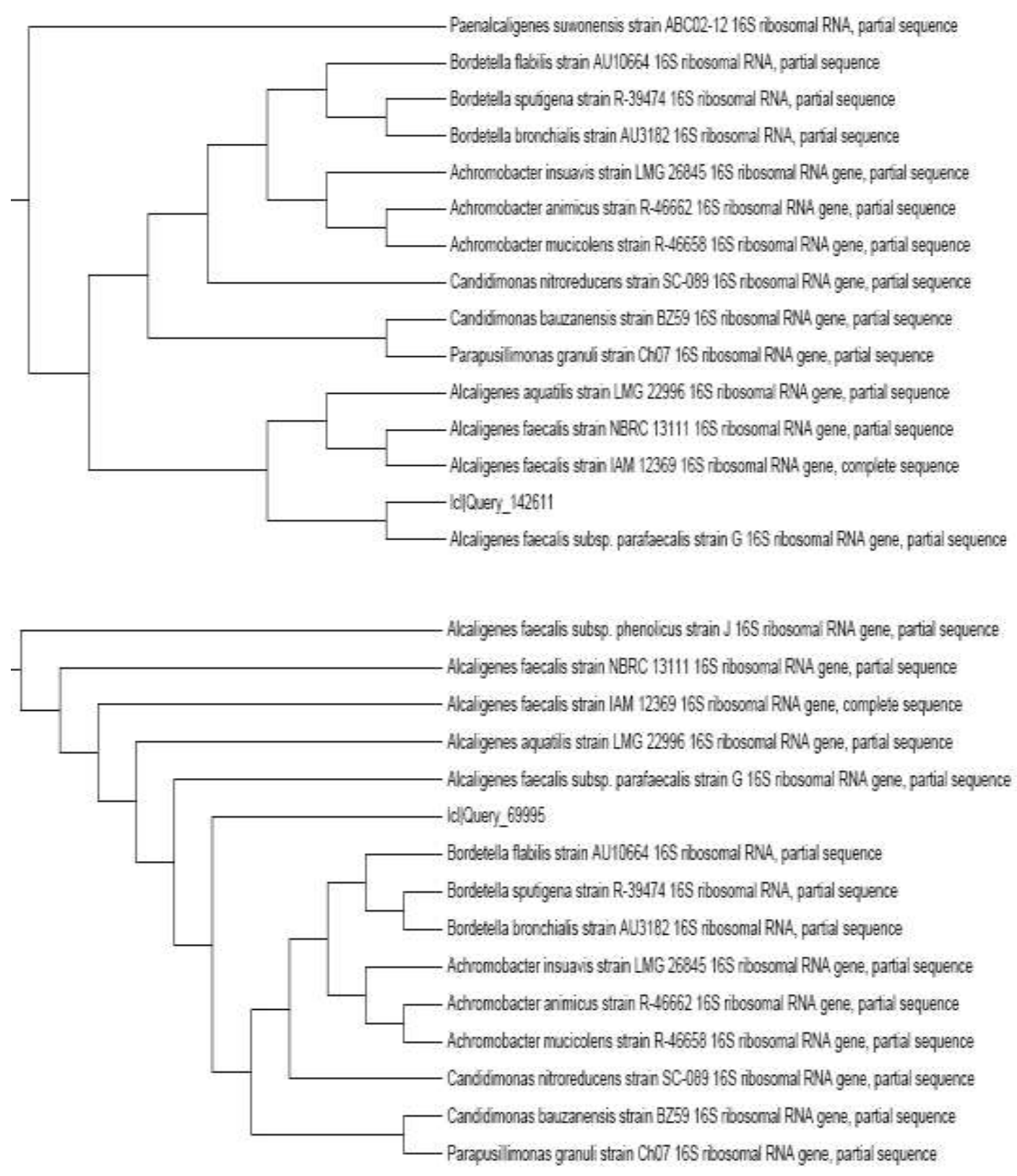

Fig - (3). Evolutionary relationships between the identified isolates and their relatives in the Gene Bank.

Egyptian J. Desert Res., 67, No. 1, 187-20 (2017) 


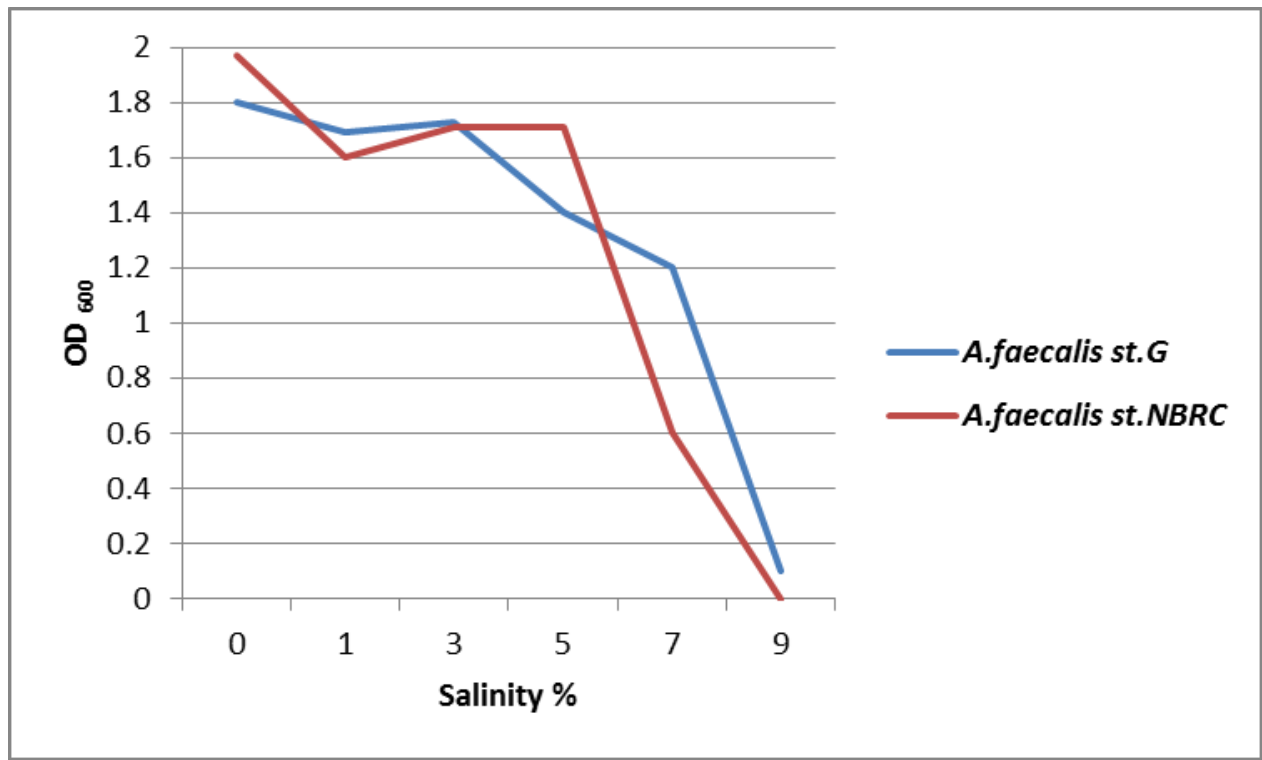

Fig. (4). Effect of salinity on the growth of ACC-deaminase bacterial strains.

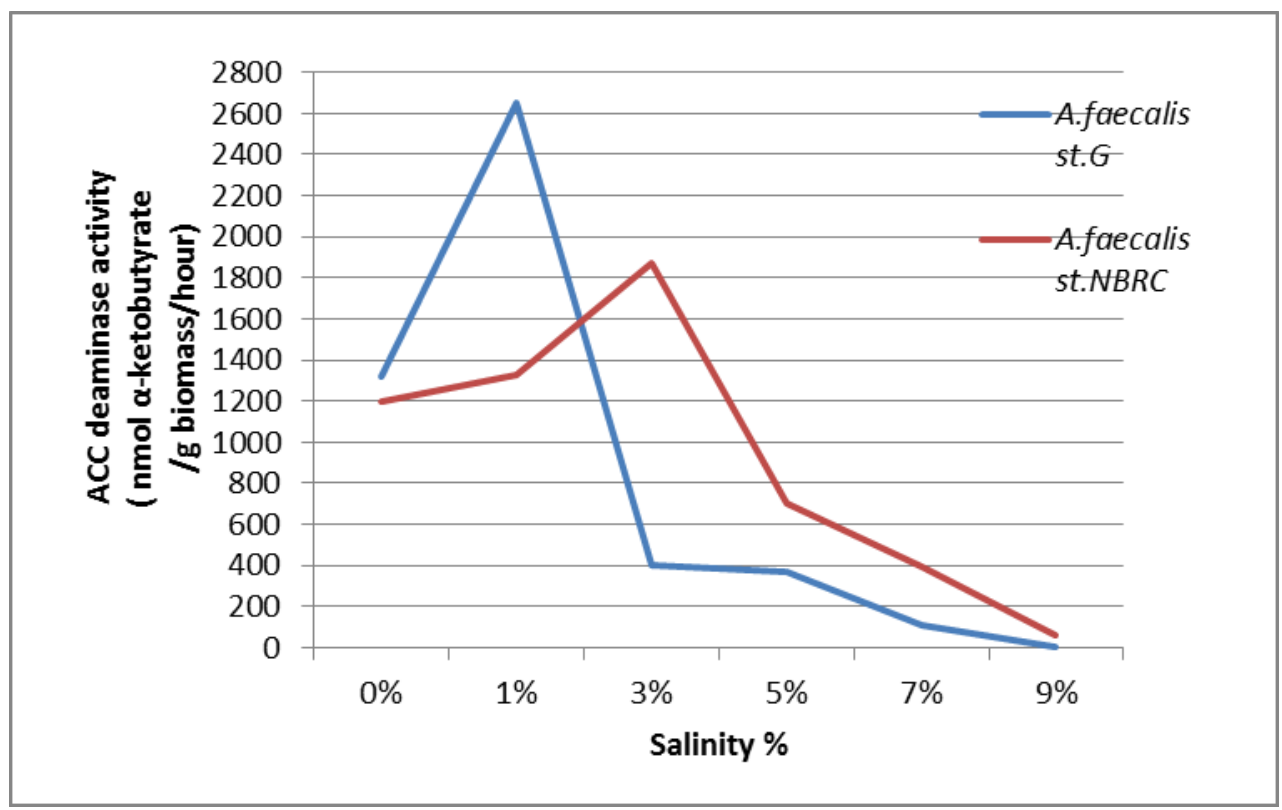

Fig. (5). Effect of salinity on the bacterial ACC-deaminase activities.

\section{Effect of ACC on the Classical Triple Response}

The experiment was conducted to demonstrate the effect of ACCdeaminase rhizobacteria and $\mathrm{C}_{2} \mathrm{H}_{4}$ released as a result of precursor (ACC) in creating classical triple response on wheat seedlings as reported in table (3). Egyptian J. Desert Res., 67, No. 1, 187-208 (2017) 
Increasing the salinity of water to $10 \% \mathrm{NaCl}$ caused a significant reduction in both stem and root length and increase in the stem diameter of seedling (classical triple response), which may be due to plant secretion of ethylene as a result of salt stress. The exogenous application of ACC to seedling under salinity stress causing a remarkable reduction in stem and root length reaching 48.7 and $70.5 \%$ and significant increasing in seedling diameters by $7.5 \%$ compared to control without ACC. Seedlings weight was also negatively affected upon addition of ACC in the growth medium that was $36.8 \%$ lesser than control without ACC. Many researchers reported that exogenously applied ACC significantly stimulate ethylene production in plant tissues (McKeon et al., 1982 and Khalid et al., 2006). Production of classical triple response due to exogenously applied ACC in etiolated tomato and Arabidopsis seedlings were reported by Barry et al. (2001), Ton et al. (2001) and Shaharoona et al. (2007).

Also, results indicated that inoculation with two ACC-deaminase rhizobacteria caused a remarkable reduction in ACC-induced classical triple response that significant increase in stem and root length and significant decrease in stem reduction compared to uninoculated ACC-stressed control were recorded. Maximum increase in seedling and root length was recorded in response to inoculation with A. faecalis st. G that were 41.4 and $34.2 \%$ higher than that recoded for ACC-stressed uninoculated control, followed by A. faecalis st. NBRC that caused 40.1 and $29.4 \%$ increase in seedling and root length than uninoculated ACC-stressed control. Inoculation with rhizobacteria caused significant decrease in stem diameter as compared with ACC stressed uninoculated control. Mayak et al. (2004) reported that Achromobacter piechaudii having ACC-deaminase activity significantly increased the fresh and dry weights of tomato seedlings grown in the presence of $\mathrm{NaCl}$ salt (up to $172 \mathrm{mM}$ ). Nadeem et al. (2010) reported that rhizobacteria capable of producing ACC-deaminase mitigate salt stress in wheat.

Table (3). Effect of ACC and ACC-deaminase strains on classical triple response.

\begin{tabular}{|c|c|c|c|c|c|}
\hline & Treatments & $\begin{array}{l}\text { Stem length } \\
\text { (cm) }\end{array}$ & $\begin{array}{l}\text { Root length } \\
\text { (cm) }\end{array}$ & $\begin{array}{c}\text { Stem diameter } \\
(\mathbf{m m})\end{array}$ & $\begin{array}{c}\text { Seedling } \\
\text { weight }(\mathrm{g})\end{array}$ \\
\hline & Control without $\mathrm{NaCl}$ & $21.6 \mathrm{a}$ & $17 \mathrm{a}$ & $1.66 \mathrm{c}$ & $0.56 \mathrm{a}$ \\
\hline & Without ACC & $7.12 b$ & $5.95 b$ & $1.84 \mathrm{~b}$ & $0.19 \mathrm{c}$ \\
\hline$\underset{\sigma}{U}$ & $\mathrm{ACC}$ & $3.65 \mathrm{~d}$ & $1.75 \mathrm{~d}$ & $1.99 \mathrm{a}$ & $0.12 \mathrm{~d}$ \\
\hline & $\mathrm{ACC}+$ A. faecalis st. $\mathbf{G}$ & $6.23 \mathrm{c}$ & $2.66 \mathrm{c}$ & $1.55 \mathrm{~d}$ & $0.23 b$ \\
\hline 8 & $\mathrm{ACC}+$ A. faecalis st. NBRC & $6.1 \mathrm{c}$ & $2.48 \mathrm{c}$ & $1.52 \mathrm{~d}$ & $0.21 \mathrm{~b}$ \\
\hline & L.S.D. $0.05 \%$ & 0.459 & 0.208 & 0.1 & 0.049 \\
\hline
\end{tabular}




\section{Field Experiments}

As the investigated soil is irrigated with saline water (EC about 7.94 $\mathrm{dSm}^{-1}$ ), reduction in all yield components was detected in uninoculated plants. Salinity may directly or indirectly inhibit cell division, cell enlargement, which results in reduction of shoot length, number of leaves, dry matter accumulation, leaf size, ear length ,grain yield, straw yield, harvest index and test weight (Francios et al., 1986; Rawson, 1988 and Asha and Dhingra, 2007).

For all traits recorded, significant increase were detected under different bacterial treatments comparing to control in both seasons of planting. The highest grain, straw and biological yield/plant in both seasons were recorded under mixed bacterial treatment with values of 15.61, 12.31 and $27.94 \mathrm{ardeb} /$ feddan at the second season, respectively. This superiority in yielding ability was attributed to increasing the number of tillers $/ \mathrm{m}^{2}$, number of spikes $/ \mathrm{m}^{2}$ and 1000-grain weight as clearly shown in table (4). For number of tillers/plants and weight of 1000-grains, significant increase with ACC-deaminase bacteria inoculation was detected without any differences between bacterial inoculation singly or as a mixture, which mean that both ACC-deaminase bacterial strains alleviated the effect of salinity stress. Arshad et al. (2008) indicated that inoculation with Pseudomonas spp. containing ACC-deaminase partially eliminates the effects of stress on growth, yield and ripening of pea. The Alcaligenes faecalis was found to have the ability to produce IAA, ACC-deaminase, phosphate solubilization and to fix atmospheric nitrogen (Neethu et al., 2016 and Amal et al., 2017).

The most common explanation for the effect of rhizobacteria on plants is based on the production of phytohormones that alter plant metabolism and morphology, leading to improved mineral and water absorption (Bashan and Levanony, 1990).

For chemical constituents of wheat grains, all bacterial treatments applied singly or as a mixture had a significant positive effect on $\mathrm{N}, \mathrm{P}$, protein and carbohydrate content of grains in both seasons as recorded in table (5). Muzaffer et al. (2014) demonstrated that plant growth promoting bacteria Alcaligenes 637Ca significantly increased fruit yield, weight of strawberry and concentrations of all plant tissue nutrients as nitrogen $(\mathrm{N})$, phosphorus $(\mathrm{P})$, potassium $(\mathrm{K})$, calcium $(\mathrm{Ca})$, iron $(\mathrm{Fe})$, copper $(\mathrm{Cu})$, manganese (Mn) and boron (B) compared to control under calcareous soil conditions. The results showed that Alcaligenes sp. could be used as biofertilizer to enhance the vigor and yield of different plants (Safa and Ali, 2011).

Egyptian J. Desert Res., 67, No. 1, 187-208 (2017) 
Table (4). Effect of two bacterial strains on different wheat growth and yield parameters.

\begin{tabular}{|c|c|c|c|c|c|c|c|}
\hline \multirow{3}{*}{ Treatments } & \multicolumn{7}{|c|}{ Growth parameters } \\
\hline & $\begin{array}{c}\text { Plant } \\
\text { height } \\
\text { (cm) }\end{array}$ & $\begin{array}{c}\text { No. of } \\
\text { tillers } / \mathbf{m}^{2}\end{array}$ & $\begin{array}{c}\text { No. of } \\
\text { spikes } / \mathbf{m}^{2}\end{array}$ & $\begin{array}{c}1000- \\
\text { grain } \\
\text { weight } \\
(\mathrm{g})\end{array}$ & $\begin{array}{c}\text { Grain } \\
\text { yield/plant } \\
\text { (ardeb/fed) }\end{array}$ & $\begin{array}{c}\text { Straw } \\
\text { yield/plant } \\
\text { (ardeb/fed) }\end{array}$ & $\begin{array}{c}\text { Biological } \\
\text { yield/plant } \\
\text { (ardeb/fed) }\end{array}$ \\
\hline & \multicolumn{7}{|c|}{ Season 1} \\
\hline Control & $65.6 \mathrm{~b}$ & $412.70 \mathrm{a}$ & $356.9 \mathrm{c}$ & $33.2 \mathrm{~b}$ & $10.05 \mathrm{c}$ & $10.35 b$ & $20.40 \mathrm{c}$ \\
\hline A. faecalis st. G & $74.3 \mathrm{a}$ & $419.40 \mathrm{a}$ & $381.5 \mathrm{~b}$ & $35.7 \mathrm{a}$ & $13.32 \mathrm{~b}$ & $10.65 \mathrm{ab}$ & $23.97 \mathrm{~b}$ \\
\hline $\begin{array}{l}\text { A. faecalis } \text { st. } \\
\text { NBRC }\end{array}$ & $73.9 \mathrm{a}$ & $418.90 a$ & $382.6 \mathrm{~b}$ & $35.6 a$ & $13.30 \mathrm{~b}$ & $10.80 \mathrm{ab}$ & $23.95 b$ \\
\hline Mixture & $74.3 \mathrm{a}$ & $421.68 \mathrm{a}$ & $395.2 \mathrm{a}$ & $36.1 \mathrm{a}$ & $14.62 \mathrm{a}$ & $11.70 \mathrm{a}$ & $26.29 \mathrm{a}$ \\
\hline L.S.D. 0.05\% & 5.4 & 11.8 & 8.74 & 0.54 & 0.165 & 1.02 & 0.645 \\
\hline \multicolumn{8}{|c|}{ Season 2} \\
\hline Control & $65.9 \mathrm{~b}$ & $418.30 \mathrm{a}$ & $368.1 \mathrm{c}$ & $33.1 \mathrm{~b}$ & $10.80 \mathrm{c}$ & $10.77 \mathrm{~b}$ & $21.57 \mathrm{c}$ \\
\hline A. faecalis st. G & $74.6 \mathrm{a}$ & $423.93 a$ & $390.3 b$ & $36.1 \mathrm{a}$ & $14.02 b$ & $11.04 \mathrm{~b}$ & $25.06 \mathrm{~b}$ \\
\hline $\begin{array}{l}\text { A.faecalis st. } \\
\text { NBRC }\end{array}$ & $74.3 \mathrm{a}$ & $423.70 \mathrm{a}$ & $389.7 b$ & $35.4 \mathrm{a}$ & $13.80 \mathrm{~b}$ & $10.98 b$ & $24.76 b$ \\
\hline Mixture & $75.1 \mathrm{a}$ & $428.30 \mathrm{a}$ & $412.7 \mathrm{a}$ & $36.7 \mathrm{a}$ & $15.61 \mathrm{a}$ & $12.31 \mathrm{a}$ & $27.94 a$ \\
\hline L.S.D. 0.05\% & 5.9 & 21.3 & 19.7 & 1.61 & 0.405 & 0.42 & 0.63 \\
\hline
\end{tabular}

Table (5). Effect of two bacterial strains on the chemical constituents of wheat grains.

Chemical constituents of wheat grains

\begin{tabular}{|c|c|c|c|c|c|c|c|c|}
\hline & \multirow{2}{*}{\multicolumn{4}{|c|}{ Season 1}} & \multirow{2}{*}{\multicolumn{4}{|c|}{ Season 2}} \\
\hline \multirow[b]{2}{*}{ Treatments } & & & & & & & & \\
\hline & N\% & $\begin{array}{c}\text { Protei } \\
\text { n } \\
\%\end{array}$ & $\mathbf{P \%}$ & $\begin{array}{c}\text { Carbohydra } \\
\text { te } \\
\%\end{array}$ & N\% & $\begin{array}{c}\text { Protein } \\
\%\end{array}$ & $\mathbf{P \%}$ & $\begin{array}{c}\text { Carbohydra } \\
\text { te } \\
\%\end{array}$ \\
\hline Control & $1.97 \mathrm{~b}$ & $12.31 \mathrm{~b}$ & $0.25 \mathrm{~b}$ & $60.2 b$ & $2.00 \mathrm{a}$ & $12.43 \mathrm{a}$ & $0.24 \mathrm{~b}$ & $60.3 b$ \\
\hline A.faecalis st. G & $2.12 \mathrm{a}$ & $13.25 \mathrm{a}$ & $0.27 \mathrm{ab}$ & $60.7 \mathrm{a}$ & $2.12 \mathrm{a}$ & $13.25 \mathrm{a}$ & $0.26 \mathrm{ab}$ & $60.7 \mathrm{ab}$ \\
\hline $\begin{array}{l}\text { A. faecalis st. } \\
\text { NBRC }\end{array}$ & $2.13 \mathrm{a}$ & $13.31 \mathrm{a}$ & $0.27 \mathrm{ab}$ & $60.6 \mathrm{a}$ & $2.13 \mathrm{a}$ & $13.31 \mathrm{a}$ & $0.28 \mathrm{a}$ & $60.7 \mathrm{ab}$ \\
\hline Mixture & $2.13 \mathrm{a}$ & $13.31 \mathrm{a}$ & $0.28 \mathrm{a}$ & $60.8 \mathrm{a}$ & $2.12 \mathrm{a}$ & $13.25 \mathrm{a}$ & $0.28 \mathrm{a}$ & $60.9 a$ \\
\hline L.S.D. 0.05\% & 0.09 & 0.56 & 0.023 & 0.59 & 0.27 & 1.68 & 0.031 & 0.658 \\
\hline
\end{tabular}

In all treatments, total microbial counts tend to increase compared to the control one as in table (6). Plants inoculated with bacterial strains produced the highest increase in the total microbial counts in both seasons regardless the type of bacteria used. This is in agreement with that 
inoculation with the plant growth promoting rhizobacteria had stimulation effect on the population of rhizosphere microorganism (Ragab et al., 2006 and Ashrafuzzaman et al., 2009). The same pattern was indicated for $\mathrm{CO}_{2}$ evolution and dehydrogenase activity of the rhizosphere regions that inoculation with any of bacterial treatment recorded the highest microbial activities. Soil respiration is very often used as an indicator of soil microflora activity. Average values of basal respiration were slightly lower $(0.45 \mathrm{mg}$ $\mathrm{CO}_{2} / \mathrm{h}$ per $100 \mathrm{~g}$ dry soil) than usual values (Popelarova et al., 2008). Increased dehydrogenase enzyme activity is proportionally linked to microbial function (Caldwell, 2005) leading to improved nutrient cycling and availability, which favors root growth and promotes beneficial plantmicrobial interactions.

Table (6). Effect of two bacterial strains on the microbiological characteristics of the rhizosphere regions.

\begin{tabular}{|c|c|c|c|c|c|c|}
\hline \multirow{3}{*}{ Treatments } & \multicolumn{6}{|c|}{ Microbiological characteristics } \\
\hline & \multicolumn{2}{|c|}{$\begin{array}{c}\text { Total microbial } \\
\text { count } * 10^{5} \text { CFU/g dry } \\
\text { soil } \\
\end{array}$} & \multicolumn{2}{|c|}{$\begin{array}{c}\mathrm{CO}_{2} \text { evaluation } \\
(\mu \mathrm{g} / \mathrm{g} \text { dry soil/ } \mathrm{h})\end{array}$} & \multicolumn{2}{|c|}{$\begin{array}{c}\text { Dehydrogenase ( } \mu \mathrm{g} \\
\text { TPF } / \mathrm{g} \\
\text { Dry soil/24 h) } \\
\end{array}$} \\
\hline & Season 1 & Season 2 & Season 1 & Season 2 & Season 1 & Season 2 \\
\hline Control & 70 & 74 & $14.3 \mathrm{~b}$ & $15.1 \mathrm{~b}$ & $123.3 \mathrm{~b}$ & $125.1 \mathrm{~b}$ \\
\hline A. faecalis st. G & 76 & 80 & $16.8 \mathrm{a}$ & $17.1 \mathrm{a}$ & $185.6 \mathrm{a}$ & $189.1 \mathrm{a}$ \\
\hline $\begin{array}{l}\text { A.faecalis st. } \\
\text { NBRC }\end{array}$ & 77 & 77 & $16.7 \mathrm{a}$ & $17.2 \mathrm{a}$ & $183.5 \mathrm{a}$ & $187.6 \mathrm{a}$ \\
\hline Mixture & 78 & 80 & $16.9 \mathrm{a}$ & $17.2 \mathrm{a}$ & $186.2 \mathrm{a}$ & $189.7 \mathrm{a}$ \\
\hline L.S.D. 0.05\% & - & - & 0.55 & 0.302 & 4.86 & 7.81 \\
\hline
\end{tabular}

\section{CONCLUSION}

Limited numbers of rhizobacteria isolated from salt-stress plants had the ability to produce ACC-deaminase enzyme with different degrees of activities. Alcaligenes faecalis strains were considered as highly efficient ACC-deaminase and growth promoting rhizobacteria. So, they can be used in practical application for promoting growth of plant species under environmental stresses.

Egyptian J. Desert Res., 67, No. 1, 187-208 (2017) 


\section{REFERENCES}

Altschul, S.F., W. Gish, W. Miller and E.W. Lipman (1990). Basic local alignment search tool. Journal of Molecular Biology, 215: 403410.

Amal, M.O., R.M. Khater and S.M. Ibrahim (2017). Using rhizobacteria and some growth promoters in improvement of Mentha viridis productivity and its antioxidants. Egyptian Journal of Applied Sciences, 32 (1): 17:40.

Arshad, M., B. Shaharoona and T. Mahmood (2008). Inoculation with Pseudomonas spp. containing ACC-deaminase partially eliminates the effects of drought stress on growth, yield, and ripening of pea (Pisum sativum L.). Pedosphere, 18: 611-620

Asha, A. and H.R. Dhingra (2007). Salinity mediated changes in yield and nutritive value of chickpea seeds. Indian J. Plant Physiol., 12 (3): 271-275.

Ashrafuzzaman, M., A.H.R.I.M. Farid, H.M.D. Anamul, I.S.M. Zahurul, S.M. Shahidullah and S. Meon (2009). Efficiency of plant growthpromoting rhizobacteria (PGPR) for the enhancement of rice growth. African Journal of Biotechnology, 8 (7): 1247-1252.

Barry, C.S., E.A. Fox, H. Yen, S. Lee, T. Ying, D. Grierson and J.J. Giovannoni (2001). Analysis of ethylene response in the epinastic mutant of tomato. Plant Physiol., 127: 58-66.

Bashan, Y. and H. Levanony (1990). Current status of Azospirillum inoculation technology: Azospirillum as a challenge for agriculture. Canadian Journal of Microbiology, 36: 591 -608.

Belimov, A.A., V.I. Safronova, T.A. Sergeyeva, T.N. Egorova, V.A. Matveyeva, V.E. Tsyganov, A.Y. Borisov, I.A. Tikhonovich, C. Kluge, A. Preisfeld, K. Dietz and V.V. Stepanok (2001). Characterization of plant growth promoting rhizobacteria isolated from polluted soils and containing 1-aminocyclopropane-1carboxylate deaminase. Canadian Journal of Microbiology, 47 (7): 642-652.

Berg, N.R., A. Steidle, L. Eberl, A. Zock and K. Smalla (2002). Plantdependent genotypic and phenotypic diversity of antagonistic rhizobacteria isolated from different verticillium host plants. Appl. Environ. Microbiol., 68: 3328-3338.

Bremner, J.M. and C.S. Mulvaney (1982). In "Nitrogen". (Page, A.L., R.H. Miller and D.R. Keeney Eds.). Methods of Soil Analysis. Part 2, Chemical and Microbiological Properties. Agronomy 9, Soc. Agron., Madison, Wisconsin, p. 595-624.

Caldwell, B.A. (2005). Enzyme activities as a component of soil biodiversity: a review. Pedobiologia, 49: 637-644.

Egyptian J. Desert Res., 67, No. 1, 187-208 (2017) 
Dey, R., K.K. Pal, D.M. Bhatt and S.M. Chauhan (2004). Growth promotion and yield enhancement of peanut (Arachis hypogaea L.) by application of plant growth-promoting rhizobacteria. Microbiological Research, 159: 371-394.

Duan, J., K.M. Muller, C. Trevor, C.S. Vesely and B.R. Glick (2009). 1amino cyclopropane-1- carboxylate (ACC) deaminase genes in rhizobia from Southern Saskatchewan. Microbial Ecology, 57: 423436.

Dubois, M., K.A. Gilles, J.K. Hamilton, P.A. Rebers and F. Smith (1956). Colorimetric method for determination of sugars and related substances. Anal. Chem., 28: 350-356.

Dworkin, M. and J. Foster (1958). Experiments with some microorganisms which utilize ethane and hydrogen. J. Bacteriol., 75: 592-601.

Francios, L.E., E.V. Mass, T.J. Donovon and V.L. Young (1986). Effect of salinity on grain yield, quality, vegetative growth and germination of semi dwarf and durum wheat. Agron. J.,78 (6): 1053-1058.

Glick, B.R. (1995). The enhancement of plant growth by free living bacteria. Can. J. Microbiol., 41: 109-117.

Glick, B.R. (2005). Modulation of plant ethylene levels by the bacterial enzyme ACC deaminase. FEMS Microbiol. Letters, 251: 1-7.

Glick, B.R., D.M. Penrose and J. Li (1998). A model for the lowering of plant ethylene concentrations by plant growth promoting bacteria. J. Theor. Biol., 190: 63-68.

Glick, B.R., C.L. Patten, G. Holguin and D.M. Penrose (1999). In "Biochemical and Genetic Mechanisms Used by Plant Growth Promoting Bacteria". Imperial College Press, London, p. 134-179.

Glick, B.R., Z. Cheng, J. Czarny and J. Duan (2007). Promotion of plant growth by ACC deaminase-producing soil bacteria. European Journal of Plant Pathology, 119, 329-339.

Govindasamy, V., M. Senthilkumar, V. Mageshwaran and K. Annapurna (2009). Detection and characterization of ACC deaminase in plant growth promoting rhizobacteria. Journal of Plant Biochemistry and Biotechnology, 18: 71-78.

Honma, M. and T. Shimomura (1978). Metabolism of 1-aminocyclopropane1-carboxylic acid. Agri. Biol. Chem., 42: 1825-1831.

Jacobson, C.B., J.J. Pasternakand and B.R. Glick (1994). Partial purification and characterization of 1-aminocyclopropane-1carboxylate deaminase from the plant growth promoting rhizobacterium Pseudomonas putida GR12-2. Can. J. Microbiol., 40: 1019-1025.

Jamil, A., S. Riaz, M. Ashraf and M.R. Foolad (2011). Gene expression profiling of plants under salt stress. Crit. Rev. Plant Sci., 30 (5): $435-458$.

Egyptian J. Desert Res., 67, No. 1, 187-208 (2017) 
Kang, B.G., W.T. Kim, H.S. Yun and S.C. Chang (2010). Use of plant growth-promoting rhizobacteria to control stress responses of plant roots. Plant Biotechnology Reports, 4: 179-183.

Kannika C. and K. Maneewan (2012). Selection of efficient salt-tolerant bacteria containing ACC deaminase for promotion of tomato growth under salinity stress. Soil Environ., 31 (1): 30-36.

Kausar, R. and S.M. Shahzad (2006) Effect of ACC-deaminase containing rhizobacteria on growth promotion of maize under salinity stress. Journal of Agriculture and Social Sciences, 2: 216-218.

Khalid, A., M.J. Akhtar, M.H. Mahmood and M. Arshad (2006). Effect of substrate- dependent microbial produced ethylene on plant growth. Microbiol., 75: 231-236.

Kohler, J., F. Caravaca, L. Carrasco and A. Roldan (2006).Contribution of Pseudomonas mendocina and Glomus intraradices to aggregates stabilization and promotion of biological properties in rhizosphere soil of lettuce plants under field conditions. Soil Use Manage., 22: 298-304.

Lane, D.J. (1991). In “16S/23S rRNA Sequencing”. (Stackebrandt, E. and M. Goodfellow Eds.), Nucleic Acid Techniques in Bacterial Systematics, Wiley, New York, p. 115-175.

Ma, W., S.B. Sebestian, J. Burd, G.I. Guinel and B.R. Glick (2003). Prevalence of 1-aminocyclopropane-1-carboxylate deaminase in Rhizobium spp. Anton. Leeuw., 83: 285-291.

Mantelin, S. and B. Touraine (2004). Plant growth promoting bacteria and nitrate availability: impacts on root development and nitrate uptake. J. Expt Bot., 55: 27-34.

Mayak, S., T. Tirosh and B.R. Glick (2004). Plant growth-promoting bacteria confer resistance in tomato plants to salt stress. Plant Physiology and Biochemistry, 42: 565-572.

McKeon T.A., N.E. Hoffmann and S.F. Yang (1982). The effect of planthormone pretreatments on ethylene production and synthesis of 1aminocyclopropane-1-carboxylic acid in water-stressed wheat leaves. Planta, 155: 437-443.

Muzaffer, I., P. Lutfi, E. Ahmet, M.F. Dönmez, M. Turan and F. Sahin (2014). Plant growth-promoting rhizobacteria increase yield, growth and nutrition of strawberry under high-calcareous soil conditions. Journal of Plant Nutrition, 37 (7): 990-1001.

Nadeem, S.M., Z.A. Zahir, M. Naveed and M. Arshad (2007). Preliminary investigations on inducing salt tolerance in maize through inoculation with rhizobacteria containing ACC-deaminase activity. Canadian Journal of Microbiology, 53: 1141-1149. 
Nadeem, S.M., Z.A. Zahir, M. Naveed, H.N. Asghar and M. Arshad (2010). Rhizobacteria capable of producing ACC-deaminase may mitigate salt stress in wheat. Soil Science of America Journal, 74: 533-542.

Neethu, S., S. Vishnupriya and J. Mathew (2016). Isolation and functional characterisation of endophytic bacterial isolates from curcuma longa. Int. J. Pharm. Bio. Sci., 7 (1): 455-464.

Neljubow, D. (1901). Uber die horizontale Nutation der Stengel von Pisutn satii'tn und einiger Anderer. Pflanzen. Beih. Bot. Zentralbl., 10:128138.

Parmer, D. and E.L. Schmidt (1964). In "Experimental Soil Microbiology". Burges Pub. Co. Minnesota, USA.

Paul, D. (2012). Osmotic stress adaptations in rhizobacteria. J. Basic Microbiol., 52: 1-10.

Penrose, D.M., M. Barbara and B.R. Glick (2001). Determination of ACC to assess the effect of ACC-deaminase-containing bacteria on roots of canola seedlings. Can. J. Microbiol., 47: 7780.

Pepper, I.L., C.P. Gerba and J.W. Brendecke (1995). In "Dehydrogenase Activity of Soils". Environmental Microbiology: A Laboratory Manual. Academic Press, New York, p. 51-56.

Peyachoknagul, S., P. Pongtongkam and S. Apisitwanich (1997). Cloning of 1-amino cyclopropane-1-carboxylate deaminase gene from soil microorganisms. Thammasat International Journal of Science and Technology, 2: 56-60.

Ping, S.Z., M. Lin, Y.N. Liu, C.B. Kauser and A. Malik (1998). Salt tolerance of diazotroph Alaligenes faecalis and its salt-tolerant association with host rice the series. Developments in Plant and Soil Sciences, 79: 87-89.

Popelářová, E., K. Voříšek and S. Strnadová (2008). Relations between activities and counts of soil microorganisms. Plant Soil Environ., 54 (4): 163-170.

Ragab, A.A., H.H. Abotaleb, Nadia M.A. and A. Ghalb (2006). Response of Lupine plants to inoculation with Bradyrhizobium sp. (Lupinus) combined with plant growth promoting Rhizobacteria (PGPR) under newly reclaimed soil condition. J. Agric. Sci. Mansoura Univ., 31 (7): 4613-4622.

Rawson (1986).Gas exchange and growth in wheat and barley grown in salt. Aust. J. Plant Physiol., 13: 475-489.

Safa A. and B. Ali (2011). Evaluation of rhizobacteria as non-rhizobial inoculants for mung beans. Australian Journal of Crop Science, 5 (13): 1723-1729.

Samasegaran, P.H., Hoben and J. Halliday (1982). In "The NIFTAL (Nitrogen Fixation in Tropical Agricultural Legumes) Manual for Methods in Legume-Rhizobium Technology". US Agency for

Egyptian J. Desert Res., 67, No. 1, 187-208 (2017) 
International Development, College of Tropical Agriculture and Resources, University of Hawai, USA.

Shaharoona, B., M. Arshad and A. Khalid (2007). Differential response of etiolated pea seedling to 1-aminocyclopropane-1-carboxylate and/or L-methionine utilizing rhizobacteria. J. Micrbiol., 45 (1): 15-20.

Shahbaz, M. and M. Ashraf (2013). Improving salinity tolerance in cereals. Crit. Rev. Plant Sci., 32: 237-249.

Snedecor, G.W. and W.G. Cochran (1990). In "Statistical Methods" 8th Ed. Iowa State Univ. Press, Ames, Iowa, USA.

Ton J., S. Davison, S.C.M. Van, L.L.C. Van and C.M.J. Pieterse (2001). The Arabidopsis ISRI locus controlling rhizobacteria-mediated induced systemic resistance is involved in ethylene signaling. Plant Physiol., 125: 652-661.

Waller, R.A. and B.D. Duncan (1969). A way for the symmetric multiple comparison Problem. Amer. Stat. Assoc. J., 3: 1485-1503.

Watanabe, F.S. and N. Olsen (1965). Test of an ascorbic acid method for determining phosphorus in soil, water and $\mathrm{NaHCO}_{3}$ extracts from soil. Soil Sci. Soc. Amer. Proc., 29: 677- 678.

Yamaguchi, T. and E. Blumwald (2005). Developing salt-tolerant crop plants: challenges and opportunities. Trends Plant Sci., 10 (12): 615-620. 


\section{إستحثاث مقاومة النبات للإجهاد الملحي بإستخدام بعض بكتيريا الريزوسفير}

أمل محمد عمر سالم

قسم خصوبة وميكروبيولوجيا الأر اضى، مركز بحوث الصحر اء، المطرية، القاهرة، مصر

تم قياس قدرة البكتيريا المعزولة من ريزوسفير بعض النباتات المزروعة في الأر اضي

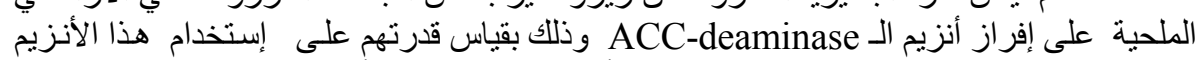

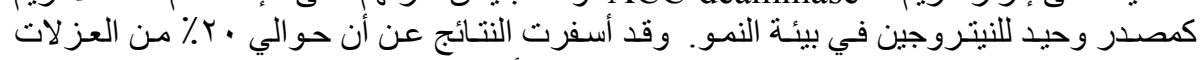

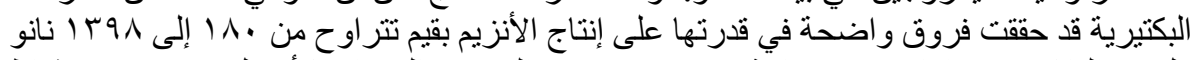

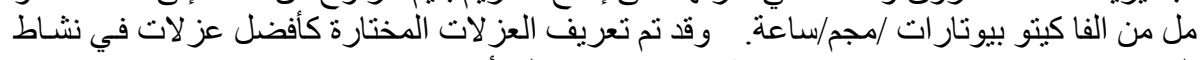

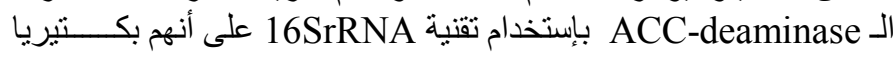

Alcaligenes faecalis subsp. parafaecalis strain $\mathrm{G} \&$ Alcaligenes faecalis strain NBRC 13111

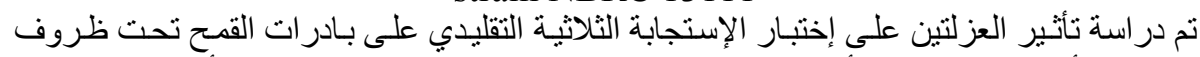

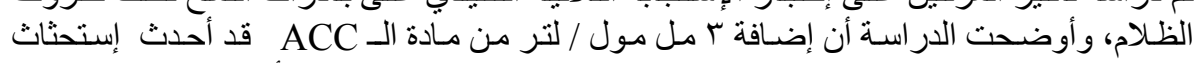

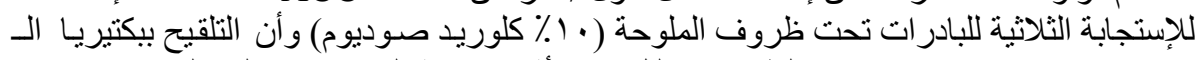
تحت هذه الظروف يقلل من تأثير إضـافة الـ ACC ACC-deaminase

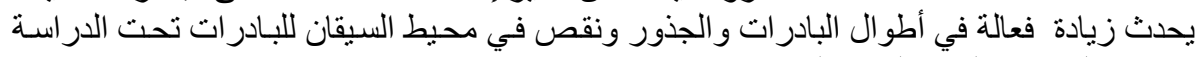
مقارنه بالبادر ات الغير ملقحة بالبكتيريا.

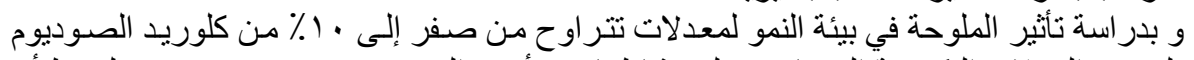

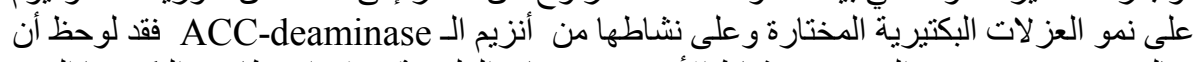

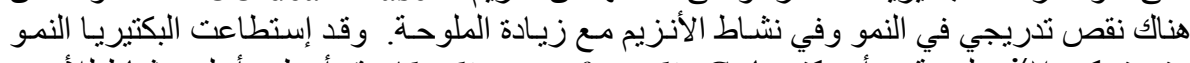

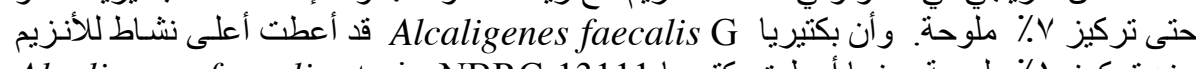

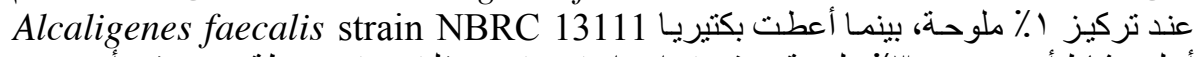

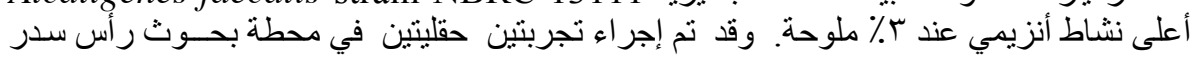

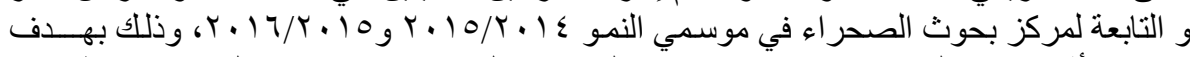

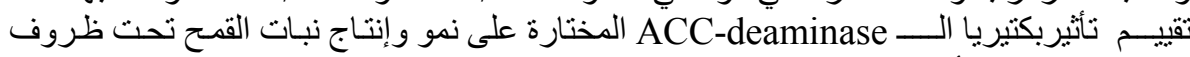

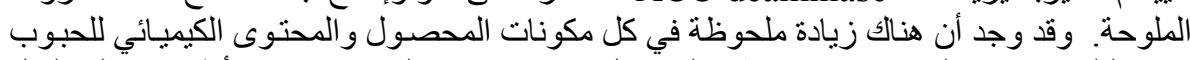

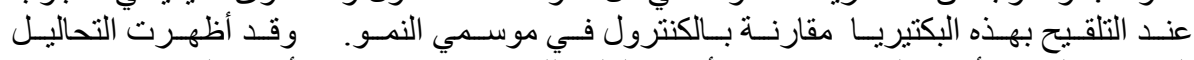

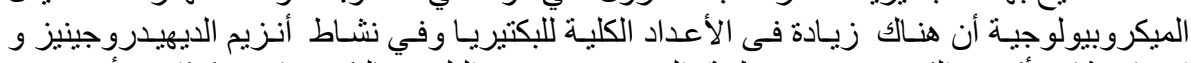

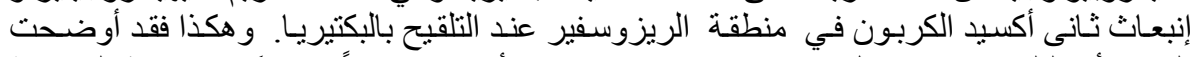

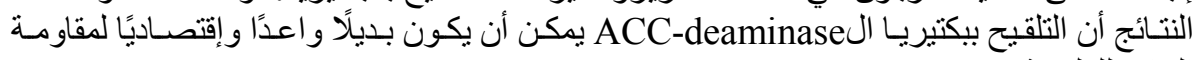

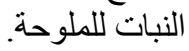

Egyptian J. Desert Res., 67, No. 1, 187-208 (2017) 